\title{
The impact of managerial communication skills on the levels of job satisfaction and job commitment
}

\author{
Meltem Paksoy ${ }^{1}$ \\ Fikret Soyer ${ }^{2}$ \\ Fehmi Çalık ${ }^{3}$
}

\begin{abstract}
The manager-employee communication is the basis of an effective management. Communication is sort of an executive skill. In this research, the aim is to determine how this skill affects the levels of job satisfaction and job commitment and whether there is a relationship between these concepts. The research was conducted by means of relational screening model and survey method was used in order to collect data. "Managerial communication skills scale" developed by Tanriverdi and colleagues (2010) for health administrators was used in evaluating managerial communication skills. In the evaluation of job satisfaction of the employees was used 5 items that measure job satisfaction developed by Brown and Peterson (1994). The sample of the study consisted of 399 people, of which 180 were female $(45.1 \%)$ and 219 were male $(54.9 \%)$, determined by random sampling method. The obtained data were analyzed by frequency analysis, T-test, cross table, simple and multiple regression models using SPSS 20.0 package program. Analyses have shown that there is a positive, bi-directional and moderate relationship between managerial communication skills and job satisfaction and job commitment levels; positive, bi-directional but weak relationship between job satisfaction and job commitment. According to the regression model developed according to research hypotheses, it is understood that managerial communication skills are effective in the level of job satisfaction and job commitment of employees. Analyses confirm all of the hypotheses. It has been proposed to increase the frequency and level of training given for the development of communication skills of managers.
\end{abstract}

Keywords: Job satisfaction; job commitment; communication; communication skills; manager.

\section{Introduction}

"The only thing that does not change is the change itself" said Heraclitus, who said that life is changing at all times. Change is an indispensable part of existence. Along with the increasing communication and globalization phenomenon brought about by the rapid change in technology, rapid changes are taking place in the cultural, political, social and economic fields all over the world. Rapid change processes have forced organizations to develop new strategies; in this sense new management paradigms have emerged. Today, the management paradigm involves a participatory process, including mutual interaction, transparent, open, fair, accountable, modern management

\footnotetext{
${ }^{1}$ Ph.D. Student, Sakarya University, Institute of Social Sciences, Department of Physical Education and Sports, meltempaksoy42@gmail.com

2 Assoc. Prof. Dr., Sakarya University, Faculty of Sports Science, Department of Physical Education and Sports, fikretsoyer@gmail.com

3 Assoc. Prof. Dr., Sakarya University, Faculty of Sports Science, Department of Physical Education and Sports, fcalik@sakarya.edu.tr
} 
Paksoy, M., Soyer, F., \& Çalık, F. (2017). The impact of managerial communication skills on the levels of job satisfaction and job commitment. Journal of Human Sciences, 14(1), 642-652. doi:10.14687/jhs.v14i1.4259

techniques (Örs \& Tetik, 2010). Communication and information-based phenomena and processes are increasingly determining the social structure (Atabek, 2001).

Effective communication is a must to successfully perform executive and organizational activities and to ensure organizational integrity (Amur 2004: 118). The communication that the organization establishes with the employee is mostly conducted by managers. A good manager is a good communicator and a good management is based on good communication skills of the manager (Tanriverdi et all., 2010). The organization will be able to achieve its goals only with dedicated employees to work and who have high job satisfaction. This is the ideal. That employees are satisfied with their jobs and they devote themselves to their jobs will benefit the organization. The question that needs to be asked at this point is this; does communication satisfaction with the manager and communication competence of the managers have any effect on the job satisfaction and job commitment levels of the employees? Are there any relationships between these concepts? The responses found will ease organizations to adapt to new management paradigms and change, be effective in their strategy developments. In this study, the concept of job satisfaction, job commitment and managerial communication skills are investigated; the relationship between these three concepts is questioned by analyzing the statistical data and then the research findings are evaluated.

\subsection{Job Satisfaction}

Conceptually, with a lot of different definitions, job satisfaction, in general terms, explains the pleasure and happiness of one's work and the factors related to it. In other words, job satisfaction is a sum of one's work-related emotional reactions (Eğinli, 2009). Locke and Henne describe job satisfaction as "the state of emotional pleasure created by the experience of someone at workplace and values that he/she attributes to work" (Oshagbemi, 2003). According to Schultz (1998), working life is expressed as a quality measure. The most important characteristic of job satisfaction is that it is an emotional concept. For this reason, the most important thing for managers to do is to help their employees reach their highest level of satisfaction (İşcan, \& Timuroğlu, 2007). The positive attitude of employees towards their work increases the level of happiness and allows positive results such as attachment to job, productive work, drop in labor turnover rate (Yüksel, 2002). Job dissatisfaction can lead people to have negative feelings and creates psychological anxiety in the workplace. This can cause the unwanted behaviors within the organization such as boredom, leaving work, absenteeism and fighting (Özkaya \& al., 2008). Job satisfaction is closely related to employee motivation. Depending on the level of motivation of the employees, it can be mentioned that the job satisfaction is high or low (Yllmaz \& Altınkurt, 2012; Can, 2016). The functions of communication in management are control, motivation, expression of emotions and thoughts, knowledge acquisition and information sharing (Robbins, 2003). Effective communication between the employees and the manager is thought to increase the motivation of the employees and increase the job satisfaction in individuals. For this reason, the most important thing for managers to do is to help their employees reach their highest level of satisfaction (İşcan, \& Timuroğlu, 2007). The positive attitude of employees towards their work increases the level of happiness and allows positive results such as attachment to job, productive work, drop in labor turnover rate (Yüksel, 2002). Job dissatisfaction can lead people to have negative feelings and creates psychological anxiety in the workplace. This can cause the unwanted behaviors within the organization such as boredom, leaving work, absenteeism and fighting (Özkaya \& al., 2008). Job satisfaction is closely related to employee motivation. Depending on the level of motivation of the employees, it can be mentioned that the job satisfaction is high or low (Yllmaz \& Altunkurt, 2012). The functions of communication in management are control, motivation, expression of emotions and thoughts, knowledge acquisition and information sharing (Robbins, 2003). Effective communication between the employees and the manager is thought to increase the motivation of the employees and increase the job satisfaction in individuals. 
Paksoy, M., Soyer, F., \& Çalık, F. (2017). The impact of managerial communication skills on the levels of job satisfaction and job commitment. Journal of Human Sciences, 14(1), 642-652. doi:10.14687/ihs.v14i1.4259

\subsection{Job Commitment (Identification)}

In the literature, the concept of commitment is defined as a positive, satisfying and spiritual situation related to work which consists of vigor, dedication and concentration (Kimura, 2011). Greenhaus (1971) defines commitment as a work's importance in an individual's life and internalization of the ideology of the work. Conceptually, it is not a momentary and peculiar situation; it is a more persistent and widespread emotional-cognitive situation that does not focus on a single object, person or behavior (Schaufeli \& al., 2002). A motivational factor that affects the performance of the organization and employees is generally seen as a part of internal motivation. It is that employees completely connect themselves to a role (Rich, Lepine and Crowford, 2010); put their "hands, mind, and heart" into action to bring out high work performance (Ashforth \& Humphrey, 1995). Job commitment has an effect on the formation of an effective organizational structure by allowing the employee to approach the work with self-sacrifice (Kahn, 1990). It was observed that employees with higher levels of job commitment had higher levels of job satisfaction, higher organizational commitment, and lower intention to leave the job (Demerouti \& Bakker, 2004, Schaufeli \& Bakker, 2004; Can, 2012). The high level of job satisfaction of individuals will increase the job satisfaction and will show itself as an effective factor in individuals' dedication to the job. Job commitment is not only a factor that leads to employee performance and organizational performance but also a concept that should be considered as a factor affecting employee attitudes at the individual level (Özyllmaz \& Süner, 2015). The sense of commitment emanates as a strong emotion that completely seizes the person in a vital sense. It is included in employee profiles that managers target and desire. Achieving this goal depends on many factors as well as on how managers use their communication methods.

\subsection{Managerial Communication Skills}

Manager is the person who is responsible for managing people, who come together for a specific purpose, in a cooperative, effective and productive manner (Erdoğan, 2000). It is primarily the manager's job to achieve the goal of the management process. Communication between the manager and the employee forms the basis of an effective management approach (Karabey \& Karcioğlu, 2008). Among the success criteria of the manager, the ability to use the communication ability is seen as an important factor and the manager has to have the skills such as leadership, motivation, communication in addition to the classical management functions. According to Shonner (1949), communication is all the processes in which an individual can affect the other. Whether written or spoken, it is the core of communication that the message has a meaning in the receiver or affect the receiver, in other terms. Through communication, members of the organization clarify the concepts and ideas in their minds, understand and influence others (Munter, 1987). Communication requires not only the transfer of meaning, but also the understanding of this meaning (Robbins, 1998). For this reason, communication is a managerial skill in a sense. Modern management concept envisages a continuous, scientific and systematic communication system for the multidimensional and environmental relations of organizations (Halis, 2000). This communication system was described by Greenberg and Baron as "a social glue that holds the organization together". Ensuring the efficient functioning of the system and evaluating the feedbacks should be seen as the primary tasks of the manager. The term "governance", which has been widely used in the literature in recent years, has emerged as a requirement of the stated function of the manager. It refers to a participatory form of government based on the interaction of governance sides derived from the combination of management, interaction and communication terms. Interaction is only possible with effective communication (Koçel, 2010).

In the light of all these, it is anticipated that the better the communication skills of managers, the more job satisfaction and job commitment. 
Paksoy, M., Soyer, F., \& Çalik, F. (2017). The impact of managerial communication skills on the levels of job satisfaction and job commitment. Journal of Human Sciences, 14(1), 642-652. doi:10.14687/jhs.v14i1.4259

\section{The Purpose of the Research}

It was aimed to determine whether the managerial communication skills have any effect on the job satisfaction and job commitment levels of the employees and whether there is any relation between the mentioned concepts.

\section{Method}

In this part of the study, the model of the research, the universe and the sample, the data collection tools, the analysis of the data and the findings are included.

\subsection{The Method of the Research}

It was attempted to determine whether the managerial communication skills have any effect on the job satisfaction and job commitment levels of the employees and whether there is any relation between the mentioned concepts The research was conducted in a relational screening model aimed at determining the presence and degree of interchange between two or more variables (Karasar, 2012). The managerial communication skills were evaluated in the "communication satisfaction with the manager" and "communication competence of the managers" subscales. Communication satisfaction with the manager, communication competence of the managers is the independent variables; job satisfaction and job commitment are used as dependent variables. The source model for research hypotheses is presented in Figure 1.

\section{Managerial Communication Skills}

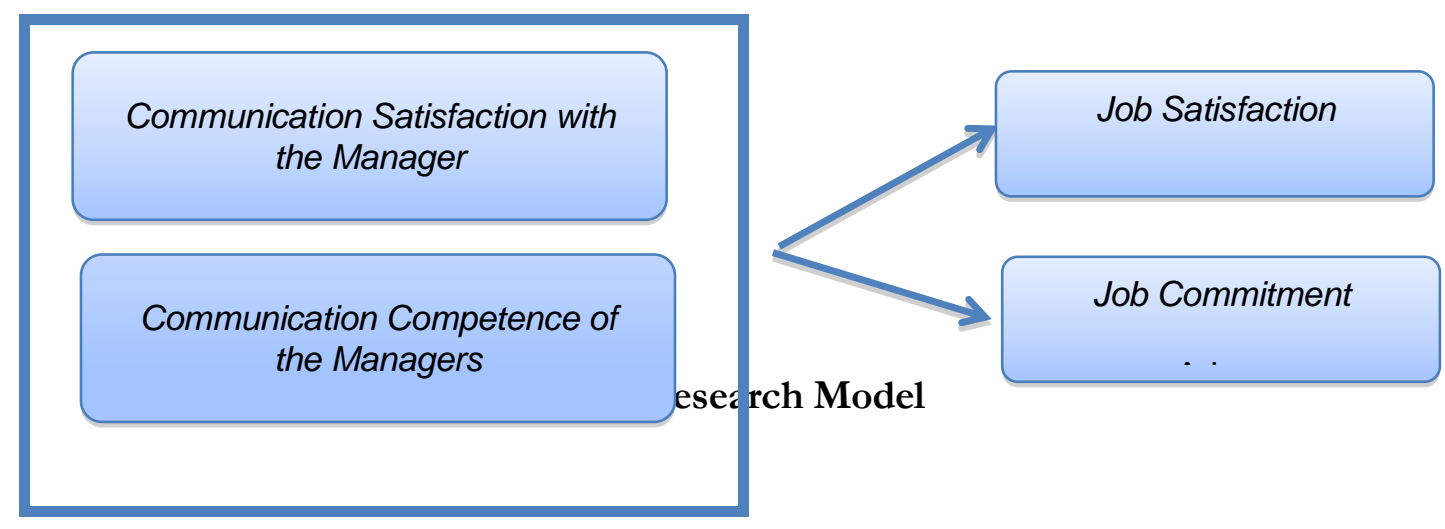

\subsection{Universe-Sample}

The universe of the research is composed of teachers and administrators working in the secondary education level attached to the Ministry of National Education in Hakkari province in 2016-2017 education year. The sample of the study is a total of 399 persons, of which 181 are women (45.4\%) and 218 are men (54.6\%), determined by random sampling method.

\subsection{Collection and Analysis of the Data}

Survey technique was used as the data collection tool in the research. Surveys were delivered directly to the participants. The prepared questionnaire consists of four parts; personal and demographic characteristics, jo commitment, managerial communication skills and job satisfaction. "Managerial communication skills scale" developed by Tanniverdi and colleagues (2010) for health administrators was used in evaluating managerial communication skills. The scale consists of 16 items and three subscales namely "communication satisfaction with the manager", "communication competence of managers", "message level and perception". "Communication satisfaction with the manager" and "communication competence of the managers" subscales were used in the research. Internal consistency coefficients (Cronbach's alpha) were 0.884 for communication satisfaction; 0.906 for communication competence and 0.932 for both subscales. 
Paksoy, M., Soyer, F., \& Çalık, F. (2017). The impact of managerial communication skills on the levels of job satisfaction and job commitment. Journal of Human Sciences, 14(1), 642-652. doi:10.14687/jhs.v14i1.4259

In the evaluation of job satisfaction of the employees, there are 5 items that measure job satisfaction developed by Brown and Peterson (1994) (Bağc1, 2014). The internal consistency coefficient (Cronbach's alpha) of the scale was 0.837.

In assessing the level of job commitment of employees, there are four items that measure job commitment level (integration, identification) developed by Britt et al. (2001). The internal consistency coefficient (Cronbach's alpha) of the scale was calculated as 0.757.

In the evaluation of the alpha coefficient, the data obtained according to the criteria indicated show that the questionnaire is very reliable (Özdamar, 2004). All of the scales were assessed with a 7 -point Likert scale $(1=$ never, $7=$ always). The survey consisted of 22 items in total, with 13 items of managerial communication skills, 5 items of job satisfaction, and 4 items of dedication to work. SPSS 20.0 package program was used in the analysis of the data. The obtained data were analyzed using frequency analysis, $t$ test, cross table, simple and multiple regression models. The results were evaluated at a significance level of 0.05 .

\subsection{Hypotheses of the Research}

For the purpose of the study, the following hypotheses were developed:

H1: There is a correlation between managerial communication skills and job satisfaction.

$\boldsymbol{H}$ : There is a correlation between managerial communication skills and job commitment.

H3: There is a correlation between job satisfaction and job commitment.

H4: Managerial communication skills have an impact on job satisfaction.

H5: Managerial communication skills have an impact on job commitment.

\section{Findings}

The data obtained on the basis of the application of the questionnaire were analyzed by the SPSS 20.0 program. The findings are explained in the tables below.

Table 1. Descriptive statistics of participants demographic characteristics

\begin{tabular}{llll}
\hline Parameters & & Frequency & Percentage (\%) \\
\hline \multirow{4}{*}{ Age } & Age 18-24 & 168 & 42.1 \\
& Age 25-31 & 127 & 31.8 \\
& Age 32-38 & 68 & 17.0 \\
\multirow{2}{*}{ Gender } & Age 39-> & 36 & 09.0 \\
\hline \multirow{3}{*}{ Work Experience } & Female & 181 & 45.4 \\
& Male & 218 & 54.6 \\
\hline \multirow{3}{*}{ Job } & $0-10$ years & 248 & 62.2 \\
& $11-20$ years & 112 & 28.1 \\
& $21->$ years & 39 & 9.8 \\
& & & \\
\hline & Preschool Teacher & 19 & 4.9 \\
& Form Teacher & 42 & 10.9 \\
& Branch Teacher & 263 & 68.1 \\
& Administrative Staff & 37 & 9.6 \\
& Administrators & 25 & 6.5 \\
\hline
\end{tabular}

Table 2. Crosstab of age and gender

\begin{tabular}{lllll}
\hline & & Female & Male & Total \\
\hline Age & Age 18-24 & 90 & 78 & 168 \\
& Age 25-31 & 57 & 70 & 127 \\
& Age 32-38 & 24 & 44 & 68 \\
& Age 39-> & 10 & 26 & 36 \\
\hline Total & & 181 & 218 & 399 \\
\hline
\end{tabular}

Table 1 shows the demographic characteristics of participants in the survey, table 2 shows the age and gender distribution of participants. According to the analysis of the tables, it was found 
Paksoy, M., Soyer, F., \& Çalık, F. (2017). The impact of managerial communication skills on the levels of job satisfaction and job commitment. Journal of Human Sciences, 14(1), 642-652. doi:10.14687/jhs.v14i1.4259

that $42.1 \%$ of the participants in the study is 90 women and 78 men in the age range of $18-24$ years, $31.8 \%$ is 57 women and 70 men in the age range of $25-31$ years, $17.0 \%$ is 24 women and 44 men in the 32-38 age range, $9 \%$ is composed of 10 women and 26 men in the age range of 51 years and more. $62.2 \%$ of participants have work experience of $0-10$ years, $28.1 \% 11-20$ years, $9.8 \% 21$ years and more. $68.1 \%$ of participants is branch teachers, $10.9 \%$ form teachers, $9.6 \%$ administrative staff, $6.5 \%$ administrators and $4.9 \%$ preschool teachers.

Table 3. Correlation analysis examining the relationship between managerial communication skills and job satisfaction and commitment

\begin{tabular}{|c|l|l|l|l|}
\hline & \multicolumn{1}{|c|}{$\begin{array}{c}\text { Managerial } \\
\text { Communication } \\
\text { Skills }\end{array}$} & $\begin{array}{c}\text { Communication } \\
\text { Satisfaction }\end{array}$ & $\begin{array}{c}\text { Communication } \\
\text { Competence }\end{array}$ \\
\hline $\begin{array}{c}\text { Job } \\
\text { Satisfaction }\end{array}$ & Pearson Correlation &, $525^{* *}$ &, $467^{* *}$ &, $506^{* *}$ \\
& Sig. (2-tailed) &, 000 &, 000 &, 000 \\
N & 388 & 388 & 388 \\
Job & Pearson Correlation &, $411^{* *}$ &, $367^{* *}$ &, $397^{* *}$ \\
Commitment & Sig. (2-tailed) &, 000 &, 000 &, 000 \\
& $\mathrm{~N}$ & 389 & 389 & 389 \\
\hline
\end{tabular}

**. Correlation is significant at the 0.01 level (2-tailed).

Correlation analysis is done to reveal the direct expression of the relationship between two variables (Köksal, 1994). The correlation coefficient is a value that measures the degree of linear relation between two variables and varies from -1 to +1 . The fact that $r$ is close to -1 indicates that there is a very strong positive linear relationship between these variables and closeness to +1 indicates a very strong positive linear relationship. If $\mathrm{r}$ is greater than 0.70 as an absolute value, it is possible to make an interpretation that the linear relationship is strong (Altunışık, Coşkun, Bayraktaroğlu, Yildirim, 2010: 227). When Table 3 is examined in the light of this information, there is a positive, bi-directional and moderate relationship between managerial communication skills and job satisfaction at $0.525^{* *}$; a positive, bi-directional and moderate relationship between the subscales communication satisfaction and job satisfaction at $0,467 * *$; a positive, bi-directional and moderate relationship between communication competence and job satisfaction at $0,506^{* *}$; a positive, bi-directional and moderate relationship between managerial communication skills and job commitment at $0,411^{* *}$; a positive, bi-directional and weak relationship between the subscales communication satisfaction and job commitment at $0,367^{* *}$; and a positive, bi-directional and weak relationship between communication competence and job commitment. According to this information, Hypothesis 1 and Hypothesis 2, which include the suggestion "There is a correlation between managerial communication skills and job satisfaction", "There is a correlation between managerial communication skills and job commitment.", are accepted.

Table4. Correlation analysis examining the relationship between job satisfaction and job commitment

\begin{tabular}{|l|l|l|}
\hline & & Job Satisfaction \\
\hline \multirow{3}{*}{ Job Commitment } & Pearson Correlation &, $288^{* *}$ \\
& Sig. (2-tailed) &, 000 \\
& $\mathrm{~N}$ & 388 \\
\hline
\end{tabular}

**. Correlation is significant at the 0.01 level (2-tailed).

When Table 4 is examined, it is seen that there is a positive, bi-directional but weak relationship between job satisfaction and job commitment at $0,288^{* *}$. Therefore, Hypothesis 3 , which includes the suggestion "There is a correlation between job satisfaction and job commitment", is accepted.

Tables 5 and 6 show the results of a simple and multiple linear regression analysis of whether managerial communication skills affect the job satisfaction and job commitment levels of employees. 
Paksoy, M., Soyer, F., \& Çalık, F. (2017). The impact of managerial communication skills on the levels of job satisfaction and job commitment. Journal of Human Sciences, 14(1), 642-652. doi:10.14687/jhs.v14i1.4259

Table5. Regression analysis examining the effect of managerial communication skills on job satisfaction

\begin{tabular}{|l|c|c|c|c|c|c|c|c|}
\hline Variables & Beta & $\mathbf{t}$ & Sig. & $\mathbf{R}$ & $\mathbf{R}^{2}$ & $\mathbf{F}$ & Sig.F & Result \\
\hline Constant & 2,110 & 8,094 &, 000 & & & & & \\
\hline $\begin{array}{l}\text { Managerial } \\
\begin{array}{l}\text { Communicati } \\
\text { on Skills }\end{array}\end{array}$ &, 581 & 12,115 &, 000 & & & & & Accepted \\
\hline
\end{tabular}

Regression analysis is a method for examining the relationship between dependent variable(s) and independent variable(s) (Özdamar, 2013). According to the regression model based on research hypotheses, job satisfaction is taken as a dependent variable and managerial communication skills is taken as an independent variable in Table 5. Statistical significance of the model is tested by ANOVA analysis. Because of Sig.F $<0,05$, it is seen that the model is statistically significant. Looking at the $\mathrm{R}^{2}$ values, which describes the variation of the independent variable over the dependent variable, $\mathrm{R}^{2}$ is calculated to be .275 . According to this, managerial communication skills account for $27.5 \%$ of total variance related to job satisfaction. According to Sig. values (P $<0.05)$, it is determined that managerial communication skills have an effect on job satisfaction of employees. In order to expand this interpretation, the effects of the subscales manager communication satisfaction and communication competence on job satisfaction are examined with multiple regression analysis in Table 6 .

Table 6. Regression analysis examining the effect of communication competence and communication satisfaction on job satisfaction

\begin{tabular}{|l|c|c|c|c|c|c|c|c|}
\hline Variables & Beta & $\mathbf{t}$ & Sig. & $\mathbf{R}$ & $\mathbf{R}^{\mathbf{2}}$ & $\mathbf{F}$ & Sig.F & Result \\
\hline Constant & 2,124 & 8,156 &, 000 & & & & & \\
\hline $\begin{array}{l}\text { Communication } \\
\text { Competence }\end{array}$ &, 348 & 5,704 &, 000 & & & & & Accepted \\
\hline $\begin{array}{l}\text { Communication } \\
\text { Satisfaction }\end{array}$ &, 228 & 3,491 &, 001 &, 528 &, 279 & 74,599 &, 000 & \\
\hline
\end{tabular}

According to the data of Table 6, it is seen that the value of $\mathrm{R}^{2}$ is calculated as .279 . According to this, it can be said that $27.9 \%$ of the total variance related to communication competence and communication satisfaction is met by job satisfaction. According to Sig. values (P $<0.05$ ), communication competence and communication satisfaction are found to have an effect on job satisfaction. In addition, managerial communication competence is more influential on job satisfaction $(\beta=.348$ and $\beta=.228)$.

Hypothesis 4, which includes the suggestion that "Managerial communication skills bave an effect on job satisfaction" is accepted as the result of this information.

In Table 7 below, simple linear regression analysis is used to examine whether managerial communication skills have an effect on job commitment.

Table 7. Regression analysis examining the effect of managerial communication skills on job commitment

\begin{tabular}{|l|c|c|c|c|c|c|c|c|}
\hline Variables & Beta & $\mathbf{t}$ & Sig. & $\mathbf{R}$ & $\mathbf{R}^{2}$ & $\mathbf{F}$ & Sig.F & Result \\
\hline Constant & 3,227 & 12,833 &, 000 & & & & & \\
\hline $\begin{array}{l}\text { Managerial } \\
\text { Communication } \\
\text { Skills }\end{array}$ &, 410 & 8,871 &, 000 & & & & & Accepted \\
\hline & & & &, 411 &, 169 & 78,694 &, 000 & \\
\hline
\end{tabular}


Paksoy, M., Soyer, F., \& Çalık, F. (2017). The impact of managerial communication skills on the levels of job satisfaction and job commitment. Journal of Human Sciences, 14(1), 642-652. doi:10.14687/jhs.v14i1.4259

According to the data of Table 7 , it is seen that the value of $\mathrm{R}^{2}$ is calculated as .169 . According to this, managerial communication skills account for $16.9 \%$ of total variance related to job commitment. According to Sig. values $(p<0.05)$, managerial communication skills are found to have an effect on job commitment. However, when the data are analyzed, it is seen that this effect is lower than the effect on job satisfaction $(\beta=.410$ and $\beta=.581)$.

Managerial communication competence seems to have more influence on job satisfaction $(\beta=.348$ and $\beta=.228)$. In order to be able to expand our interpretation, the effects of the subscales manager communication satisfaction and communication competence on job commitment are examined with multiple regression analysis in Table 8.

Table 8. Regression Analysis Examining the Effect of the Communication Competence and Communication Satisfaction on Job Commitment

\begin{tabular}{|c|c|c|c|c|c|c|c|c|}
\hline Variables & Beta & $\mathrm{t}$ & Sig. & $\mathbf{R}$ & $\mathbf{R}^{2}$ & F & Sig.F & Result \\
\hline Constant & 3,236 & 12,864 & ,000 & & & & & \\
\hline $\begin{array}{l}\text { Communication } \\
\text { Competence }\end{array}$ & ,245 & 4,150 & ,000 & & & & & Accepted \\
\hline $\begin{array}{l}\text { Communication } \\
\text { Satisfaction }\end{array}$ & 163 & 2,573 & ,010 & ,414 & ,171 & 39,931 &, 000 & \\
\hline
\end{tabular}

When the data in Table 8 are examined, it is seen that the $\mathrm{R}^{2}$ value is calculated as .171 . Accordingly, managerial communication skills account for $17.1 \%$ of the total variance related to job commitment. It appears that managerial communication competence has more influence on job commitment $(\beta=.245$ and $\beta=.163)$.

Hypothesis 5, which includes the suggestion that "Managerial communication skills have an effect on job commitment", is accepted as the result of evaluation of the data.

\section{Discussion, Results and Recommendations}

Organizational communication, which expresses the communication mechanisms and processes that occur among the employees in the organization, is seen as an important tool used to influence the behavior of individuals (Ellis, 1976). There is not much work in the literature on how the communication skills of managers influence the employees, even though communication inside the organization has been the subject of many academic studies. Karabey and Karcı $\breve{l} l u$ also pointed out the same point in their work and stated that despite the fact that there are some studies on the effect of the managers' communication on the work results of the employees (e.g.: Yüksel, 2005; Eronat, 2004, Minister and Büyükbeşe, 2004), not sufficient attention has been drawn to the subject.

In the research, it is attempted to determine how the degree of managers' use of communication skills affects the level of job satisfaction and job commitment of employees and whether there is any relation between these concepts. The relationship between managerial communication skills, job satisfaction and job commitment variables is tested by correlation analysis (Table 3). Accordingly, there is a positive, bi-directional and moderate relationship between managerial communication skills and job satisfaction at $0.525^{* *}$; a positive, bi-directional and moderate relationship between the subscales communication satisfaction and job satisfaction at $0,467^{* *}$; a positive, bi-directional and moderate relationship between communication competence and job satisfaction at $0,506^{* *}$; a positive, bi-directional and moderate relationship between managerial communication skills and job commitment at $0,411^{* *}$; a positive, bi-directional and weak relationship between the subscales communication satisfaction and job commitment at 0,367**; and a positive, bi-directional and weak relationship between communication competence and job commitment. According to this information, Hypothesis 1 "There is a correlation between managerial communication skills and job satisfaction", Hypothesis 2 "There is a correlation between managerial 
Paksoy, M., Soyer, F., \& Çalık, F. (2017). The impact of managerial communication skills on the levels of job satisfaction and job commitment. Journal of Human Sciences, 14(1), 642-652. doi:10.14687/jhs.v14i1.4259

communication skills and job commitment." and Hypothesis 3 "There is a correlation between job satisfaction and job commitment" are accepted.

It was tested by simple and multiple linear regression analyzes whether managerial communication skills are influential on job satisfaction and job commitment levels of employees. The statistical significance of the regression model that was formed by taking research hypotheses into consideration was tested by ANOVA analysis. For Sig.F $<0.05$, the model is found to be significant. Looking at the $\mathrm{R}^{2}$ values, which describe the variation of the independent variable over the dependent variable, $\mathrm{R}^{2}$ was calculated to be .275 . According to this, managerial communication skills account for $27.5 \%$ of total variance related to job satisfaction. According to Sig. values $(\mathrm{p}<0.05)$, it was determined that managerial communication skills have an effect on job satisfaction of employees. In order to extend this interpretation, we investigated the effects of multiple regression analysis and the subscales on managerial communication satisfaction and communication competence on job satisfaction. The $\mathrm{R}^{2}$ value is calculated to be .279 . Accordingly, communication competence and communication satisfaction account for $27.9 \%$ of total variance related to job satisfaction. According to Sig. values $(p<0.05)$, communication competence and communication satisfaction are found to have an effect on job satisfaction. In addition, managerial communication competence is more influential on job satisfaction $(\beta=.348$ and $\beta=.228$ ). Hypothesis 4, which includes the suggestion that "Managerial communication skills have an effect on job satisfaction", is accepted as the result of this information.

It has been examined with simple linear regression analysis whether managerial communication skills have an effect on job commitment. The R2 value, according to the analysis, has been calculated as 169 . Under these circumstances, it seems that managerial communication skills meet $16.9 \%$ of the total variance related to job commitment. According to Sig. values $(p<0.05)$, managerial communication skills have been found to have an effect on job commitment. However, when the data are examined, it is understood that this effect is lower than the effect on job satisfaction $(\beta=.410$ and $\beta=.581)$.

When the data is analyzed, it is seen that manager communication competence has more effect on job satisfaction $(\beta=.348$ and $\beta=.228)$.

The effect of the subscales manager communication satisfaction and communication competence on job commitment has been tested by multiple regression analysis. The R2 value is calculated as .171. Accordingly, managerial communication skills account for $17.1 \%$ of the total variance related to job commitment. It appears that manager communication competence has more influence on job commitment ( $\beta=.245$ and $\beta=.163$ ). Hypothesis 5 , which includes the suggestion that "Managerial communication skills have an effect on job commitment", is accepted as the result of evaluation of the data.

Downs and Hazen, 1977; Pincus, 1986; Meyer and Allen, 1991; Karabey and Karcioğlu, 2008; Match, 2010; Tanriverdi et al., 2010; Aydogan and Kaşkaya, 2010; Ünler et al., 2014 are seen as studies that directly or indirectly support our findings. It has been emphasized in the studies that managerial communication skills have an effect on employee motivation, managers' communication skills have a key role in reaching the goal of the managerial process, employees who have better communication with managers and higher job satisfaction have lower intention to leave the job and there is a positive relationship between job satisfaction and managerial communication skills. The feature that distinguishes our work from other work in the related field is that it examines whether managerial communication skills have an effect on job commitment as well as job satisfaction.

It is important for the people in any managerial position at any stage to be able to adequately use the communication methods and to ensure the continuity of the communication methods. It is incontrovertibly high what positive values employees with high job satisfaction and commitment add to the organization. For this purpose, it is suggested to increase the frequency and level of trainings given to improve the communication skills of managers. 
Paksoy, M., Soyer, F., \& Çalık, F. (2017). The impact of managerial communication skills on the levels of job satisfaction and job commitment. Journal of Human Sciences, 14(1), 642-652. doi:10.14687/jhs.v14i1.4259

\section{References}

Altunışık, R., Coşkun, R., Bayraktaroğlu, S., Yıldırım, E., (2010). Research Methods in Social Sciences (with SPSS application) (6 $6^{\text {th }}$ edition). Sakarya: Sakarya Publishing.

Ashforth, B. E. and Humphrey, R. H. (1995), "Emotion in the Workplace: A Reappraisal" Human Relations. Atabek, Ü. (2001). Communication and Technology, Seçkin Publishing, Ankara.

Aydoğan, İ. \& Kaşkaya, A. (2010). "The Evaluation of Communication Skills of Primary School Administrators According to Views of Administrators and Teachers". Journal of Gazi Educational Faculty, 30(1), 1-16.

Bağc1, Z. (2014). The Effect of Job Satisfaction of Employee On Task and Contextual Performance. Journal of Management and Economic Studies, 12(24), 58-72.

Bakan, İ. and Büyukbeşe, T. (2004), "The Relationship Between Organizational Communication and The Aspects of Job Satisfaction: A Field Study for Academic Organizations", Journal of Akdeniz I.I.B.F.

Bitmiş, M. G., Güney, S., \& Demirel, H. (2014). The Role of Organizational Commitment and Job Satisfaction in Communication Satisfaction and Productivity Relationship: A Test of Multiple Mediation Model. Hacettepe University Journal of Economics \& Administrative Sciences, 32(2).

Britt, T. W., Adler, A. B., \& Bartone, P. T. (2001). Deriving Benefits from Stressful Events: The Role of Engagement in Meaningful Work and Hardiness. Journal of occupational health psychology, 6(1),53.

Can, Y. (2012), Sport satisfaction and organizational commitment relation: A study on Turkish football coaches Energy Education Science and Technology Part B: Social and Educational Studies, 2012 Volume (issue) 4(3): 1465-1472.

Can, Y. (2016). Sporcuların iş tatmini spor tatmini ve örgütsel bağlılık duygularının yaşam tatmini üzerindeki etkisinin incelenmesi. Journal of Human Sciences, 13(3), 5248-5256.

Demerouti, E., Bakker, A. B., De Jonge, J., Janssen, P. P., \& Schaufeli, W. B. (2001). Burnout and Engagement at Work as A Function of Demands and Control. Scandinavian journal of work, environment \& health, 279-286.

Downs, C. W., M. D. Hazen (1977) “A Factor Analytic Study of Communication Satisfaction”, Journal of Business Communication, 14(3), 63-73.

Eğinli, A. T. (2009). Job Satisfaction of Employees: A Research on Job Satisfaction of the Employees in Public and Private Sector. Atatürk University Journal of Economics and Administrative Sciences, 23(3).

Ellis, D.S. (1976) The Central Role of Communication in Complex Organizations. In J.L. Owen, P.A. Page, G.I. Zimmerman (eds.), Communication in Organizations, New York: West Publishing Co.

Erdoğan, İ. (2000). School Management and Educational Leadership. İstanbul: Sistem Publishing.

Eronat, Zeynep (2004), "Communication as a Factor in the Solution of the Job Satisfaction and Turnover Problems at Managements: An Empirical Application in SMEs", Unpublished Master's Thesis, Ankara University Institute of Social Sciences.

Greenberg, Jerald ve Robert Baron (2000), Behavior in Organizations, New Jersey: Prentice Hall.

Greenhaus, J. H. (1971). An Investigation Of The Role Of Career Salience In Vacational Behavior. Journal of Vocational Behavior, 1, 209-216.

Halis, M. (2000). A Research on Organizational Communication and Communication Satisfaction. Atatürk University Journal of Economics and Administrative Sciences, 14(1).

İşcan, Ö. F., \& Timuroğlu, M. K. (2007). The Effect of Organizational Culture on Job Satisfaction and an Application. Atatürk University Journal of Economics and Administrative Sciences,21(1).

Kahn, W. A. (1990), "Psychological Conditions Of Personal Engagement And Disengagement At Work", Academy of Management Journal, 33, 692-724.

Karabey, C., \& Karcioğlu, F. (2008). The Relationships Between Supervisors' Communication Styles and Employees' Perceptions of Job Satisfaction, Performance and Role Ambiguity. Eskişehir Osmangazi Journal of Economics and Administrative Sciences, 3(2), 25-42.

Karasar, N. (2012). The Method of Scientific Research: Concepts, Principles, Techniques. Nobel Publishing Distribution.

Koçel, T. (2010). Management Administration. İstanbul: Beta Publishing. 12 $2^{\text {th }}$ ed.

Köksal, Bilge A. (1994), Statistics Analysis Method, Çağlayan Publishing, İstanbul.

Maçin, E. (2010). “The Effects of Managerial Communication Skills on Employee Motivation”, Unpublished Master's Thesis, Beykent University Institute of Social Sciences. 
Paksoy, M., Soyer, F., \& Çalik, F. (2017). The impact of managerial communication skills on the levels of job satisfaction and job commitment. Journal of Human Sciences, 14(1), 642-652. doi:10.14687/jhs.v14i1.4259

Metin, H. (2011). Empathic Communication and Governance. Journal of Communication Theory and Research, 32,177-203.

Meyer, J. P., N. J. Allen (1991) "A Three-Component Conceptualization of Organizational Commitment", Human Resource Management Review, 1(1), 61-89.

Munter Mary, Business Communication: Strategy and Skill, NJ: Prentice Hall Int., 1987.

Oshagbemi, T. (2000) "Is Length of Service Related to The Level Of Job Satisfaction?", International Journal Of Social Economics, 27 (3), Pp. 213-226.

Örs, F., \& Tetik, S. (2010). New Management Paradigms in Globalizing World: Change and Communication. Çukurova University Journal of the Institute of Social Sciences, 19(3).

Özdamar, K. (2004). Data Analysis with Package Programs. Kaan Publishing, Eskişehir.

Özdamar, K. (2013). Statistical Data Analysis with Package Programs (Analysis with Multiple-Variables) 2, $9^{\text {th }}$ ed., Eskişehir.

Özkaya, M. O., YAKIN, V., \& Ekinci, T. (2008). Effect of Stress Levels Upon the Job Satisfaction of The Employees An Empirical Study on Employees of Celal Bayar University, Management and Economy: Celal Bayar University Journal of the Faculty of Economics and Administrative Sciences, 15(1), 163-179.

Özyllmaz, A., \& Süner, Z. (2015) The Effect of Job Engagement on Job Attitudes: Results of Empirical Research Conducted in 9 Business Organizations in Hatay.

Pincus, J. D. (1986) "Communication Satisfaction, Job Satisfaction, and Job Performance", Human Communication Research, 12(3), 395-419.

Potvin, T. C. (1991) Employee Organizational Commitment: An Examination of its Relationship to Communication Satisfaction and Evaluation of Questionnaires Designed to Measure the Construct, Unpublished Doctoral Dissertation. University of Kansas.

Rich, B. L., Crawford, E. R. ve Lepine, J. A. (2010), "Job Engagement: Antecedents and Effects on Job Performance", Academy of Management Journal, 53, 617-635.

Robbins, S. P. (1998). Organizational Behavior Concepts, Contioversies, Applications, Prentice Hall International, San Diego.

Robbins, S. P. (2003). Essentials of Organizational Behavior (Seventh Edition). New Jersey: Prentice Hall.

Schaufeli, W. B, Salanova, M., González-Romá, V., \& Bakker, A. B. (2002). The Measurement of Engagement and Burnout: A Two Sample Confirmatory Factor Analytic Approach, Journal of Happiness Studies, 3, 71-92.

Schultz, D. \& Schultz S. E. (1998), Pschology and Work Today. Prentice-Hall Inc, New Jersey, 7. Edition.

Shonner, C., \& Worren W. (1949), The Mathematical Theory of Communication, Univercity Ilinois Pres.

Tanrıverdi, H., Adıgüzel, O., \& Çiftçi, M. (2010). The Impacts of the Health Managers' Communicational Efficiency On the Performance of the Staff: A Case of State Hospital. Journal of Süleyman Demirel University Institute of Social Sciences Year, 1(11).

Tutar, H. (2003). Organizational Communication. Ankara: Seçkin Publishing.

Ünler, E., Kılıç, B., \& Çıray, J. C. (2014). The Moderating Effect of Communication Climate Between Job Satisfaction and Turnover Intention. Journal of Marmara University Social Sciences Institute/Öneri, 11(41).

Yilmaz, K., \& Altınkurt, Y. (2012). Relationship Between School Administrators Power Sources and Teachers' Job Satisfaction. Kastamonu Education Journal, 20(2), 385-402.

Yüksel, İ. (2002), "The Determination of the Factors of Job Satisfaction Differentiating the Job Satisfaction Levels of Nurses", Koceli University Journal of the Institute of Social Sciences Volume 3, Issue 1.

Yüksel, İ. (2005), "The Effects of Communication On Job Satisfaction: An Empiric Study in A Firm", Journal of Doğuş University, 6 (2), 291-306. 